\title{
PENGARUH CARA PENGAWETAN TERHADAP SIFAT FISIS \\ KULIT KELINCI REX BERBULU
}

Widari, Meiyanti, Titik purwati W, Sudirman

\section{ABSTRACT}

This experiment was done to compare the preservation (curing) method of for Rex rabbit skin on their physical properties tensile strength, tear strength and stick-tear strength. The raw material used in this experiment were 36 pieces rabbit skin. The skins devided in to three curing methods were salted, dry salted and combination dry salted and poison each nine pieces respectively. Nine pieces for uncured/fresh skins used as control. The cured and uncured skins were than processed as finished leather. The physical properties of cured finish leather were analyzed and compare with physical properties of uncured leather. The physical properties of uncured leather had better quality compared than cured leather.

\section{RINGKASAN}

Penelitian ini bertujuan untuk mengetahui pengaruh terhadap sifat fisis (kekuatan tarik, kekuatan sobek dan kekuatan jahit) kulit kelinci Rex berbulu. Materi yang digunakan adalah kulit kelinci Rex sebanyak 36 lembar, terdiri dari 9 lembar kulit awet garam basah, 9 lembar kulit awet kering dan 9 lembar kulit awet kering menggunakan racun dan 9 lembar kulit segar sebagai kontrol. Dari pengujian fisis terhadap kulit jadinya diperoleh hasil bahwa kulit jadi yang berasal dari kulit segar kualitasnya lebih baik dibanding kulit yang mengalami proses pengawetan.

\section{PENDAHULUAN}

Kulit adalah hasil dari peternakan, merupakan komoditi ekspor yang dapat diandalkan dan masih mendominasi dalam pembuatan produk sepatu, glove, garment dan barang-barang lainnya.

Menurut Raharjo (1990), kelinci mampu tumbuh dan berkembang biak dengan cepat serta dapat dipelihara dengan mudah dan murah. Bulu kelinci Rex halus, tebal, seragam panjangnya, tidak mudah rontok dan menarik penampilannya. Kulit kelinci Rex tersebut diperoleh setelah pemotongan hewan, dari tempat pengulitan sampai tempat penyamakan/pengolahan kulit membutuhkan waktu yang cukup lama, sehingga kulit perlu diawetkan agar tidak mudah rusak. Pengawetan kulit bertujuan untuk memperpanjang masa 
simpan kulit dan untuk melindungi kulit tersebut terhadap serangan bakteri hingga penyamak kulit siap untuk memulai pengolahan kulit tersebut.

Pengawetan kulit kelinci dapat dilakukan dengan berbagai cara antara lain dengan cara penggaraman dan dikeringkan. Pengawetan dengan cara penggaraman menggunakan garam dapur sebagai bahan pengawet. Sedangkan pengawetan dengan cara dikeringkan dapat dilakukan dengan sinar matahari tanpa menggunakan racun dan dapat juga dikeringkan menggunakan racun sebagai bahan pengawet

\section{MATERI DAN METODA PENELITIAN}

\section{Materi Penelitian}

Untuk penelitian ini menggunakan kulit kelinci Rex : segar, awet garam basah, awet kering dan awet kering menggunakan racun (hide poison) sebanyak 36 lembar. Kulit kelinci tersebut diperoleh dari Balai Penelitian Ternak-Bogor.

Khemikalia yang digunakan adalah khemikalia untuk penyamakan yaitu : bahan penyamak krom, bahan penyamak sintetis, dan bahan pembantu penyamakan antara lain : $\mathrm{NaCl}, \mathrm{COOH}, \mathrm{Na}-\mathrm{Fo}, \mathrm{Na}_{2} \mathrm{CO}_{3}$.

Sedangkan alat/mesin yang digunakan antara lain : drum penyamakan, timbangan, gantungan kulit.

Metoda Penelitian

Kulit kelinci Rex sebanyak 36 lembar dibagi menjadi 4 kelompok, masing-masing : 9 lembar kulit kelinci Rex segar; 9 lembar kulit kelinci Rex awet garam basah; 9 lembar kulit kelinci Rex awet kering dan 9 lembar kulit kelinci Rex awet kering menggunakan racun (hide poison).

Kulit kelinci segar digunakan sebagai kontrol, tanpa perlakuan pengawetan.

Penelitian dimulai dari proses penyamakan kulit mentah menjadi kulit jadi yaitu kulit berbulu dengan formula yang sama.

Setelah proses penyamakan, kulit kelinci berbulu diuji fisis mengenai : tebal, kekuatan tarik, kekuatan sobek dan kekuatan jahit.

Untuk pengujian fisis dari masing-masing perlakuan pengawetan dan kontrol menggunakan 4 lembar kulit kelinci sebagai sampel.

Formula dan tahapan proses penyamakan sebagai berikut :

1. Pencucian : $1000 \%$ air

$0,5 \%$ sandozin NIL

2. Degreasing : $100 \%$ air

$0,5 \%$ sandopan DTC

putar selama 60 menit kemudian dicuci sampai bersih dengan air mengalir
3. Pikel/pengasaman :
$100 \%$ air
$10 \% \quad \mathrm{NaCl}$
10 menit
$\% \mathrm{HCOOH}$
15 menit

\section{Putar selama 15 menit, kemudian diam} kan semalam ( 20 jam )

Keesokan hari $\mathrm{pH}$ dicek $=3$ dan penampang kulit berwarna kuning terhadap BCG. Kemudian dilakukan pembuangan lemak.

\section{Penyamakan}

Ditambah

\section{Netralisir}

6. Penyamakan ulang :

7. Peminyakan
$\%$ formali

$\mathrm{pH}=3,5$

Diamkan semalam ( \pm 20 menit )

$\begin{array}{ll}\% & \text { krom } \\ \% & \mathrm{Na}_{2} \mathrm{CO}_{3} \\ \% & \mathrm{NaHCO}_{3}\end{array}$

$\% \mathrm{NaHCO}_{3}$

$\mathrm{pH}=4,5$

Diamkan semalam ( \pm 20 menit). Keesokan hari, drum diputar selama 15 menit, kemudian di cuci bersih denagan air mengalir.

\section{$\%$ air}

$1 \% \mathrm{Na}_{2} \mathrm{CO}_{3}$ $\mathrm{pH}=5-5,5$

Penampang kulit biru terhadap BCG, kemudian cuci bersih

:

$100 \%$ air $60^{\circ} \mathrm{C}$

$5 \%$ Tergotan LS

$3,5 \%$ Basyntan 60 menit

Diamkan semalam (20 menit). Cuci bersih dengan air mengalir.

$100 \%$ air $60^{\circ} \mathrm{C}$

$6 \%$ minyak

$0,5 \% \mathrm{HCOOH}$

60 menit 


\section{$2 \%$ Eskatan GLH}

Drum diputar sampai $\mathrm{pH}: 4$. Kemudian dicuci dengan air mengalir.

8. Pekerjaan mekanis meliputi :

Penirisan, pengeringan, perenggangan, milling, dan perapian.

Pengujian

Kulit jadi hasil penelitian diuji sifat fisisnya, meliputi tebal, kekuatan tarik, kekuatan sobek dan kekuatan jahit.

\section{Analisa data}

Data hasil uji fisis dianalisa secara statistik menggunakan rancangan acak lengkap. Apabila terdapat perbedaan, diuji menggunakan Duncan's test.

\section{MASIL DAN PEMBAHASAN}

Dari pengujian fisis kulit kelinci Rex berbulu, diperoleh hasil :

Tabel 1 : Tebal Kulit Kelinci Rex Berbulu (mm)

\begin{tabular}{c|c|c|c|c}
\hline \multirow{2}{*}{ No. } & \multicolumn{4}{|c}{ Variasi perlakuan } \\
\cline { 2 - 5 } & segar & garam & kering & kering + racun \\
\hline 1. & 0,80 & 0,98 & 1,40 & 0,92 \\
2. & 0,84 & 0,84 & 0,76 & 0,72 \\
3. & 0,66 & 0,70 & 0,90 & 0,78 \\
4. & 0,66 & 0,68 & 0,86 & 0,78 \\
\hline
\end{tabular}

Tidak terdapat perbedaan yang nyata $(P \leq 0,05)$ tebal rata-rata kulit kelinci Rex dari kulit segar dan kulit kelinci yang diawetkan menggunakan garam basah, kering diberi racun dan kering biasa.

F terhitung : 1,$33 ; \mathrm{F}$ tabel $: 3,49$. Tebal rata-rata kulit kelinci Rex adalah : 0,8 $\mathrm{mm} \pm 0,17 \mathrm{~mm}$.

Tabel 2: Hasil Uji Kekuatan Tarik Kulit Kelinci Rex Berbulu $\left(\mathrm{km} / \mathrm{cm}^{2}\right)$

\begin{tabular}{c|c|c|c|c}
\hline \multirow{2}{*}{ No. } & \multicolumn{4}{|c}{ Variasi perlakuan } \\
\cline { 2 - 5 } & segar & garam & kering & kering + racun \\
\hline \multirow{2}{*}{1.} & 85,33 & 157,01 & 36,00 & 47,33 \\
2. & 92,57 & 126,32 & 32,97 & 40,44 \\
3. & 91,78 & 55,56 & 36,75 & 129,32
\end{tabular}

\begin{tabular}{l|r|r|r|r}
4. & 82,44 & 32,25 & 27,14 & 97,14 \\
5. & 105,43 & 118,00 & 59,56 & 47,43 \\
6 & 97,14 & 83,54 & 46,89 & 55,34 \\
7. & 80,86 & 40,00 & 26,67 & 113,75 \\
8. & 71,43 & 47,62 & 21,33 & 98,44 \\
\hline
\end{tabular}

Dari analisa statistik ternyata terdapat perbedaan yang sangat nyata $(\mathrm{P} \leq$ 0,01 ) dengan $F$ terhitung $=5,08$ antara kulit segar, kulit awet garam basah dan kulit awet kering menggunakan racun terhadap kulit awet kering tanpa menggunakan racun. Sedangkan kekuatan tarik antara kulit segar, kulit awet garam basah dan kulit awet kering menggunakan racun tidak terdapat perbedaan yang nyata $(\mathrm{P} \leq 0,05)$

Kekuatan tarik tertinggi berasal dari kulit kelinci Rex segar, sebesar $=(88,37$ $\pm 9,41) \mathrm{kg} / \mathrm{cm} 2$; kemudian berturut-turut adalah : kulit kelinci Rex awet ga$\mathrm{ram}=\left(82,54\right.$ 土13,31) $\mathrm{kg} / \mathrm{cm}^{2} ;$ kulit kelinci kering diberi racun $=(78,65$ 土 $12,58) \mathrm{kg} / \mathrm{cm} 2$ dan terendah adalah kekuatan tarik dari kulit kelinci Rex awet kering $=(35,91 \pm 11,53) \mathrm{kg} / \mathrm{cm}^{2}$

Tabel 3, Hasil Uji Ketahanan Sobek Kulit Kelinci Rex Berbulu (kg/cm)

\begin{tabular}{c|c|c|c|c}
\hline \multirow{2}{*}{ No. } & \multicolumn{4}{|c}{ Variasi perlakuan } \\
\cline { 2 - 5 } & segar & garam & kering & kering + racun \\
\hline 1. & 15,71 & 20,50 & 8,57 & 8,20 \\
2. & 14,57 & 19,25 & 6,53 & 6,00 \\
3. & 17,14 & 11,50 & 5,78 & 16,33 \\
4. & 21,00 & 11,11 & 8,33 & 11,25 \\
5. & 16,89 & 12,86 & 6,60 & 2,86 \\
6. & 21,00 & 13,67 & 7,78 & 5,00 \\
7. & 14,67 & 13,00 & 5,78 & 10,86 \\
8. & 20,00 & 14,00 & 7,20 & 11,67 \\
\hline
\end{tabular}

Dari perhitungan statistik ternyata terdapat perbedaan yang sangat nyata ( $P$ $\leq 0,01)$ antara kulit kelinci Rex segar dan kulit kelinci Rex awet garam dengan kulit kelinci Rex awet kering (menggunakan racun dan kering biasa).

Tidak ada perbedaan yang nyata $P \leq 0,05$ antara :

- Kulit kelinci Rex awet segar dengan kulit kelinci Rex awet garam

- Kulit kelinci Rex awet kering menggunakan racun dengan kulit kelinci Rex awet kering tanpa menggunakan racun.

Vol IX No. 18 Tahun 1993/1994 
Kekuatan sobek tertinggi adalah kulit kelinci segar sebesar 17,62 $\pm 2,52$ $\mathrm{kg} / \mathrm{cm}$; berturut-turut kemudian kulit kelinci awet garam $=14,49 \pm 3,26$ $\mathrm{rg} / \mathrm{cm}$; kulit kelinci awet kering menggunakan racun $=9,02 \pm 4,07 \mathrm{~kg} / \mathrm{cm}$ lan terendah adalah kulit kelinci awet kering $=7,07 \pm 1,01 \mathrm{~kg} / \mathrm{cm}$.

Tabel 4 : Hasil Uji Kekuatan Jahit Kulit Kelinci Rex Berbulu (kg/cm)

\begin{tabular}{l|l|l|l|l}
\hline \multirow{2}{*}{ No. } & \multicolumn{4}{|c}{ Variasi perlakuan } \\
\cline { 2 - 5 } & segar & garam & kering & kering + racun \\
\hline 1. & 78,33 & 44,23 & 58,33 & 45,56 \\
2. & 78,33 & 54,20 & 47,23 & 36,91 \\
3. & 83,33 & 60,25 & 45,50 & 74,33 \\
4. & 76,50 & 59,60 & 44,55 & 71,43 \\
5. & 66,25 & 65,25 & 68,50 & 63,33 \\
6. & 81,11 & 64,33 & 50,00 & 50,86 \\
7. & 82,00 & 62,00 & 69,00 & 68,00 \\
8. & 70,00 & 45,00 & 40,44 & 70,22 \\
\hline
\end{tabular}

ari perhitungan statistik, terdapat perbedaan yang sangat nyata $P \leq 0,01$ intara : kulit kelinci segar dengan kulit kelinci Rex yang diawet garam, dawet kering diberi racun dan kering biasa.

ridak ada perbedaan yang nyata $\mathrm{P} \leq 0,05$ antara : kulit kelinci awet garam, wet kering diberi racun dan kering biasa.

Kekuatan jahit tertinggi adalah kulit kelinci segar, sebesar : 76,98 $\pm 5,59$ $\mathrm{g} / \mathrm{cm}$. Kemudian berturut-turut kulit kelinci awet kering menggunakan racun $=60,08 \pm 12,95 \mathrm{~kg} / \mathrm{cm}$; kulit kelinci awet garam $=56,86 \pm 7,74 \mathrm{~kg} / \mathrm{cm}$. Dan kekuatan tarik terendah adalah kulit kelinci Rex awet kering $=52,94 \pm$ $10,32 \mathrm{~kg} / \mathrm{cm}$.

Berdasarkan data hasil uji fisis dan perhitungan statistik dari uji : tebal kulit, sekuatan tarik, kekuatan sobek, kekuatan jahit ternyata kulit jadi yang berasal dari kulit segar kualitasnya lebih baik dibandingkan kulit kelinci Rex ang sưah mengalami pengawetan. Kulit kelinci segar mempunyai kekuatan arik, kekuatan sobek dan kekuatan jahit tertinggi dibanding kulit kelinci ang diawet kering, kering menggunakan acun dan diawet menggunakan garam basah.

Kulit hewan terdiri dari tiga lapisan utama, salah satu lapisan kulit ini adalah korium yang terdiri dari serabut kolagen, elastin dan retikuler. Serabut-seraout ini menentukan kualitas kulit, karena jaringan dalam korium mudah dioengruhi keadaan luar, suhu, kelembaban udära dan sanitasi (Ditjen Pet. 1978). Selain itu sebab-sebab kulit mentah perlu diawet adalah karena ada- nya penundaan sebelum dilakukan proses penyamakan. Karena kulit segar langsung diproses tanpa mengalami penundaan maka jaringan kulit tidak banyak mengalami perubahan, kualitas kulit jadinya lebih baik dibanding kulit kelinci yang sudah mengalami proses pengawetan

Kulit kelinci Rex diawet menggunakan garam basah, kualitasnya lebih baik dibanding kulit-kulit kelinci yang diawet secara dikeringkan dan yang dikeringkan menggunakan racun

Garam merupakan bahan pengawet, bukan pembunuh kuman, tetapi berfungsi mengurangi kadar air di dalam kulit. Garam akan menempati ruangan dalam kulit yang biasanya ditempati oleh air, menarik air dari dalam kulit sehingga kandungan air berada dibawah batas minimum untuk hidup dan tumbuhnya bakteri pembusuk. Dengan demikian kulit sudah diawet dan dapat disimpan sebagai kulit awetan sampai saatnya kulit-kulit tersebut diproses selanjutnya.

Pada pengawetan menggunakan garam basah, hanya terjadi sedikit kerusakan kulit, karena tidak terjadi reaksi kimia antara garam dan kulit. Struktur jaringan kulit masih baik karena serabut kolagen menjadi kompak, tidak mudah rusak sehingga hasil uji fisisnya lebih baik dibanding kulit yang diawet kering.

Kulit yang diawet kering menggunakan sinar matahari sangat tergantung dari ada tidaknya sinar matahari.

Apabila terjadi kesalahan pada waktu pengeringan karena terlalu cepat atau terlalu lambat akan menyebabkan kerusakan dari jaringan atau serabut kolagen, serabut kolagen akan menjadi "getas" mudah putus, sehingga kualitas kulit menjadi turun.

Pada pengawetan secara dikeringkan sering ditambahkan racun yang bersifat sebagai bahan pengawet. Racun yang sering digunakan dalam pengawetan kulit adalah Natrium Arsenit atau preparat arsen lainnya (Wikantadi. B.,1972). Natrium Arsenit diperdagangkan sebagai "Hide poison", digunakan sebagai insektisida dan bersifat mengawet. Dengan demikian struktur jaringan kulit keadaannya akan lebih baik daripada kulit yang diawet kering tanpa menggunakan racun. Sehingga kualitas kulit kelinci Rex yang diawet kering menggunakan racun "hide poison" lebih baik dibanding kulit kelinci Rex yang diawet kering tanpa menggunakan racun.

\section{KESIMPULAN}

Dari hasil penelitian dapat diambil beberapa kesimpulan :

1. Kulit mentah segar yang langsung diproses/disamak, menghasilkan kulit jadi bermutu tinggi .

2. Kualitas kulit jadi yang berasal dari kulit mentah awet garam basah, lebih baik dibanding kulit kelinci Rex yang diawet kering dengan sinar matahari.

Vol IX No. 18 Tahun 1993/1994 
3. Dari kulit kelinci yang diawet kering menggunakan racun, menghasilkan kulit jadi yang mutunya lebih baik dibanding kulit yang diawet kering tanpa menggunakan racun.

\section{SARAN}

1. Untuk keadaan yang memungkinkan sebaiknya kulit segar langsung diproses atau disamak tanpa proses pengawetan

2. Unutk kulit mentah yang perlu diawet dalam jangka waktu relatif singkat (kurang dari satu bulan), sebaiknya diawet menggunakan garam basah.

3. Apabila kulit kelinci Rex akan diawet kering, sebaiknya ditambah khemikalia/racun pembunuh kuman, serangga.

\section{DAFTAR PUSTAKA}

1. Arrington, LR and KC. Kelley, 1976. "Domestic Rabbit Biology and Production" The University Press of Florida Gainesville (USA).

Busono, 962. "Struktur Kulit atau Susunan Jaringan Kulit".

3. Hari Nugroho, 1982. "Beberapa Pengamatan Management Ternak Kelinci". Universitas Brawijaya Malang, Indonesia

4. Steel, RGO and JH. Torrie, 1960. "Principle and Procedures of Statistic". Mc. Graw Hill Book Co. Inc. New York, Toronto.

Rismunandar, 1970. "Meningkatkan Konsumsi Protein dengan Beternak Kelinci" Penerbit CV. Sinar Baru Bandung, 1981 